\title{
Assessment of Spatial Variability of Heavy Metals in Metropolitan Zone of Toluca Valley, Mexico, Using the Biomonitoring Technique in Mosses and TXRF Analysis
}

\author{
Graciela Zarazúa-Ortega, ${ }^{1}$ Josefina Poblano-Bata, ${ }^{2}$ Samuel Tejeda-Vega, ${ }^{1}$ \\ Pedro Ávila-Pérez, ${ }^{1}$ Carmen Zepeda-Gómez, ${ }^{2}$ \\ Huemantzin Ortiz-Oliveros, ${ }^{1}$ and Guadalupe Macedo-Miranda ${ }^{3}$ \\ ${ }^{1}$ Environmental Science Division, National Institute for Nuclear Research, Carretera México-Toluca S/N, \\ La Marquesa, 52750 Ocoyoacac, MEX, Mexico \\ ${ }^{2}$ Autonomous University of Mexico State, Unidad San Cayetano, 50294 Tlachaloya, MEX, Mexico \\ ${ }^{3}$ Technology Institute of Toluca, Apartado Postal 890, 52149 Metepec, MEX, Mexico \\ Correspondence should be addressed to Graciela Zarazúa-Ortega; graciela.zarazua@inin.gob.mx
}

Received 10 April 2013; Accepted 26 May 2013

Academic Editors: A. J. Aller, A. A. El-Sayed, A. A. Menegário, and C. Pistos

Copyright (C) 2013 Graciela Zarazúa-Ortega et al. This is an open access article distributed under the Creative Commons Attribution License, which permits unrestricted use, distribution, and reproduction in any medium, provided the original work is properly cited.

\begin{abstract}
This study is aimed at assessing atmospheric deposition of heavy metals using the epiphytic moss genera Fabronia ciliaris collected from six urban sites in the Metropolitan Zone of the Toluca Valley in Mexico. The concentrations of K, Ca, Ti, V, Cr, Mn, Fe, $\mathrm{Ni}, \mathrm{Cu}, \mathrm{Zn}, \mathrm{Rb}, \mathrm{Sr}$, and $\mathrm{Pb}$ were determined by total reflection $\mathrm{X}$-ray fluorescence technique. Results show that the average metal concentration decrease in the following order: $\mathrm{Fe}(8207 \mathrm{mg} / \mathrm{Kg})>\mathrm{Ca}(7315 \mathrm{mg} / \mathrm{Kg})>\mathrm{K}(3842 \mathrm{mg} / \mathrm{Kg})>\mathrm{Ti}(387 \mathrm{mg} / \mathrm{Kg})>\mathrm{Mn}, \mathrm{Zn}$ $(191 \mathrm{mg} / \mathrm{Kg})>\mathrm{Sr}(71 \mathrm{mg} / \mathrm{Kg})>\mathrm{Pb}(59 \mathrm{mg} / \mathrm{Kg})>\mathrm{Cu}, \mathrm{V}(32 \mathrm{mg} / \mathrm{Kg})>\mathrm{Cr}(24 \mathrm{mg} / \mathrm{Kg})>\mathrm{Rb}(13 \mathrm{mg} / \mathrm{Kg})>\mathrm{Ni}(10 \mathrm{mg} / \mathrm{Kg})$. Enrichment factors show a high enrichment for $\mathrm{Cr}, \mathrm{Cu}, \mathrm{Zn}$, and $\mathrm{Pb}$ which provides an evidence of anthropogenic impact in the industrial and urban areas, mainly due to the intense vehicular traffic and the fossil fuel combustion. Monitoring techniques in mosses have proved to be a powerful tool for determining the deposition of heavy metals coming from diverse point sources of pollution.
\end{abstract}

\section{Introduction}

Atmospheric pollution has become one of the most important issues of air quality due to its impact on human health and the environment. Suspended particulates are introduced into the atmosphere from a variety of natural and anthropogenic sources, although the latter are predominant in the urban and industrial areas. Some of the well known anthropogenic processes contributing to the airborne particulate pollution include transportation, industrial activities, biomass burning and agricultural activities. In the case of anthropogenic pollution, the particulate matter can contain metal trace element like $\mathrm{Cr}, \mathrm{Cu}, \mathrm{Zn}, \mathrm{Ni}, \mathrm{Pb}$, and so forth [1].

Biomonitoring methods have become an important part of air pollution measurements. They are a widely available and effective means to determine "the levels of air pollutants and their impact on biological receptors" $[2,3]$ and therefore complement instrumental measurement methods.

Due to their peculiar morphological and physiological characteristics mosses (division Bryophytes) are useful indicators of a wide range of contaminants. Bryophytes are poikilohydric species with a diverse means for water and mineral uptake [4]. As most bryophytes are small and the leaves of many mosses and folious liverworts consist of only one cell layer, the surface-to-volume ratio is high.

Bryophytes are resistant against many substances which are highly toxic for other plants. As a consequence of their nutrient cycling and uptake mechanisms they tend to accumulate pollutants. Bryophytes show several advantages as biomonitors of atmospheric deposition over other species, such as the lack of a protective cuticle and thick cell walls, numerous cell wall constituents with negatively charged 
TABLE 1: Description of sampling locations at the Metropolitan Zone of the Toluca Valley.

\begin{tabular}{|c|c|c|c|c|c|}
\hline \multirow{2}{*}{ Reference } & \multirow{2}{*}{ Sampling site } & \multicolumn{2}{|c|}{ Geographic location } & \multirow{2}{*}{$\begin{array}{c}\text { Altitude } \\
\text { masl }\end{array}$} & \multirow{2}{*}{ Description } \\
\hline & & $\begin{array}{l}\text { North } \\
\text { latitude }\end{array}$ & $\begin{array}{c}\text { West } \\
\text { longitude }\end{array}$ & & \\
\hline Alameda & 1 & $19^{\circ} 17^{\prime} 23^{\prime \prime}$ & $99^{\circ} 39^{\prime} 43^{\prime \prime}$ & 2662 & Urban park with high traffic \\
\hline Reforma & 2 & $19^{\circ} 17^{\prime} 27^{\prime \prime}$ & $99^{\circ} 38^{\prime} 29^{\prime \prime}$ & 2644 & Urban park with high traffic \\
\hline Hipico & 3 & $19^{\circ} 15^{\prime} 50^{\prime \prime}$ & $99^{\circ} 37^{\prime} 54^{\prime \prime}$ & 2668 & Urban park with high traffic \\
\hline Pila & 4 & $19^{\circ} 15^{\prime} 36^{\prime \prime}$ & $99^{\circ} 35^{\prime} 15^{\prime \prime}$ & 2623 & Urban park with medium traffic \\
\hline Santin & 5 & $19^{\circ} 21^{\prime} 9^{\prime \prime}$ & $99^{\circ} 35^{\prime} 31^{\prime \prime}$ & 2596 & Urban area with medium traffic \\
\hline Tollocan & 6 & $19^{\circ} 17^{\prime} 10^{\prime \prime}$ & $99^{\circ} 32^{\prime} 49^{\prime \prime}$ & 2589 & Urban, industrial, and highway with the highest traffic \\
\hline Cacalomacan & 7 & $19^{\circ} 11^{\prime} 57^{\prime \prime}$ & $99^{\circ} 44^{\prime} 04^{\prime \prime}$ & 3100 & $\begin{array}{l}\text { Ecological park without urban settlements, nondisturbed by } \\
\text { pollution }\end{array}$ \\
\hline Ciervita & 8 & $19^{\circ} 11^{\prime} 17^{\prime \prime}$ & $99^{\circ} 48^{\prime} 35^{\prime \prime}$ & 3317 & $\begin{array}{l}\text { Natural protected area without urban settlements, } \\
\text { non-disturbed by pollution }\end{array}$ \\
\hline
\end{tabular}

groups, mineral nutrition obtained mainly from wet and dry deposition, and widespread distribution of several species together with simplicity and cheapness of biomonitoring methods $[5,6]$.

Mosses have been extensively employed over the past 30 years to monitor and map atmospheric deposition of contaminants, especially trace metals, in different parts of the world, due to the high correlation between deposition rates and levels in moss tissues [7-11].

Recently, these organisms are being used to determine patterns of variation across the regions, identify the main polluted areas, and develop the understanding of long-range transboundary pollution [12] because metals are present in much higher concentrations in mosses compared with the levels in precipitation samples, where the detection limit is usually too low and contamination problems can occur [1316].

The aim of the present study was to evaluate atmospheric deposition of heavy metals using as indicator the epiphytic moss genera Fabronia ciliaris from the Metropolitan Zone of the Toluca Valley in Mexico applying the Total Reflection XRay Fluorescence Spectrometry (TXRF) technique.

\section{Experimental}

2.1. Sampling Area. The Metropolitan Zone of the Toluca Valley (MZTV) is located in the central region of Mexico, in the Estado de Mexico, between $19^{\circ} 05^{\prime}$ and $19^{\circ} 25^{\prime}$ north latitude and $99^{\circ} 20^{\prime}$ y $99^{\circ} 50^{\prime}$ west longitude, and is situated in an area known as the Mexican Highlands (2660 masl). Using Köppen's climatic classification [17], the Valley of Toluca presents a $\mathrm{C}(\mathrm{w} 2)(\mathrm{w}) \mathrm{bi}(\mathrm{g})$ climate, which corresponds to a subhumid temperate climate, with a long summer, winter rain of less than $5 \%$, isothermal, and with maximum temperatures before the summer solstice. The MZTV is one of the five largest urban areas $\left(1208 \mathrm{~km}^{2}\right)$ in Mexico and is an important center for industrial and agricultural activity, with a high population density [18].

Six urban sites to the MZTV (Table 1; Figure 1) were selected taking into account the impact of industrial and urban pollution sources and the species of epiphytic moss Fabronia ciliaris being representative. At each sampling location 10 trees were selected and were taken $10 \mathrm{~cm}^{2}$ of epiphytic mosses; they were obtained at a height greater than one meter. Sampling was done in November 2010, that corresponding to dry-cold season.

2.2. Sample Preparation. The sample mosses were carefully washed with distilled water, freeze-dried, ground, sifted to 200 mesh, and homogenized. $0.3 \mathrm{~g}$ subsample of each site was putted in a closed digestion vessel was added $4 \mathrm{~mL}$ of $\mathrm{HNO}_{3}$ and allowed to pre-digest for 12 hours [19], then each of the samples was added with $1 \mathrm{~mL}$ of $\mathrm{HCl}$ and digested in a microwave furnace (CEM-MarsX): increasing the temperature in $30 \mathrm{~min}$ to $170^{\circ} \mathrm{C}, 300 \mathrm{psi}$, and $15 \mathrm{~min}$ of maintenance time [20]. Then, $1.5 \mathrm{~mL}$ of $\mathrm{H}_{2} \mathrm{O}_{2}$ was added to the sample before the second digestion under the same conditions as aforementioned.

The digested sample was transferred into a volumetric flask, the reaction vessels were washed out with deionized water, and the flask volume made up to a final volume of $10 \mathrm{~mL} .100 \mu \mathrm{L}$ of Ge standard solution (Merck) of $20 \mu \mathrm{g} / \mathrm{mL}$ was added as internal standard to $1 \mathrm{~mL}$ subsample of the digested samples and mixed. After that, $10 \mu \mathrm{L}$ of the digested and standardized sample was deposited on a silicon quartz glass holder, and dried under infrared light [21]. Only supra pure grade quality chemicals were used. All samples were digested in duplicate.

2.3. Sample Analysis. The TX 2000 X-Ray Spectrometer manufactured by Ital Structures was used in order to obtain the elemental concentration. A primary fine focus beam provided by the X-Ray tube with a molybdenum anode is monochromatized and is directed to the sample at a glancing angle less than the critical angle. The tube was operated at $40 \mathrm{kV}$ and $30 \mathrm{~mA}$. The fluorescent X-rays derived from the sample were detected with a solid state lithium-drifted silicon detector of $20 \mathrm{~mm}^{2}$ front area, cooled with liquid nitrogen. The energy resolution (FWHM) of the $\mathrm{Si}(\mathrm{Li})$ detector was $140 \mathrm{eV}$ for $\mathrm{Mn} \mathrm{K} \alpha$ and its beryllium window was $8 \mu \mathrm{m}$ thick.

Three replicates were analyzed for each sample in order to evaluate the reproducibility of measurements. All samples were excited for $500 \mathrm{~s}$. Heavy metal concentration 


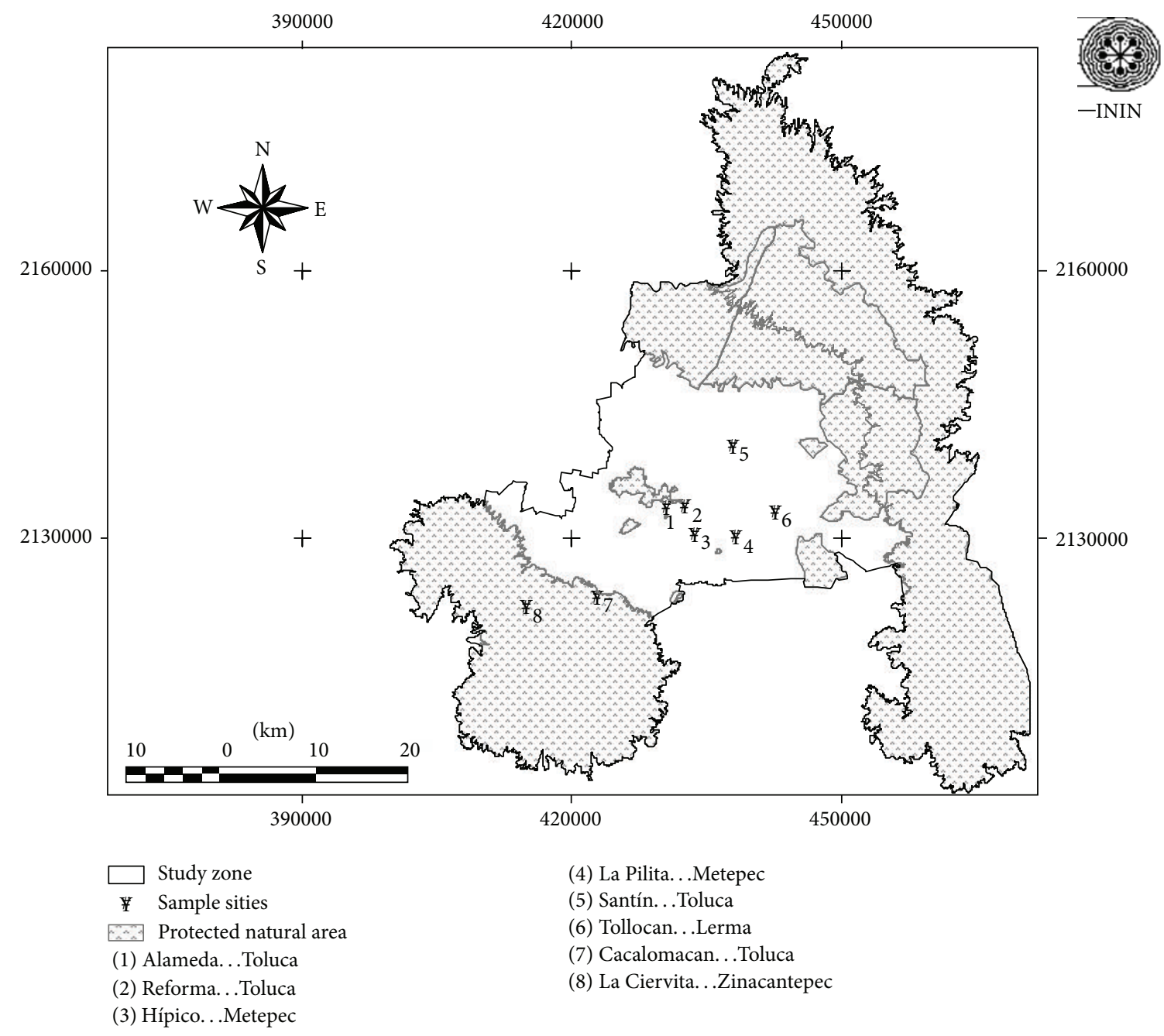

FIGURE 1: Geographical distribution of sampling locations at the Metropolitan Zone of the Valley of Toluca.

was determined by internal standardization; this method is appropriate for a multielement determination and is normally used for TXRF. It is based on the sensitivity values of the different elements. For the analysis of the spectra and metal quantification, the software EDXRF32 was used [22]. Method detection limit (MDL) listed in Table 3 was calculated with the following formula [23]:

$$
\mathrm{MDL}=3\left(\frac{C_{x}}{I_{x}}\right)\left(\sqrt{2} I_{\mathrm{BG}}\right),
$$

where MDL is method detection limit (minimum detectable mass $\mathrm{mg} / \mathrm{Kg}) ; C_{x}$ is analyte concentration $(\mathrm{mg} / \mathrm{Kg}) ; I_{x}$ is analyte net intensity (counts); and $I_{\mathrm{BG}}$ is background intensity (counts).

2.4. Enrichment Factors. Enrichment factors (EFs) were also investigated. This factor estimates the enrichment of $\mathrm{K}, \mathrm{Ca}, \mathrm{V}$, $\mathrm{Cr}, \mathrm{Mn}, \mathrm{Fe}, \mathrm{Ni}, \mathrm{Cu}, \mathrm{Zn}$, and $\mathrm{Pb}$ by terrestrial or anthropogenic effects using (2). Titanium was selected as conservative element [24]. Values of reference soil, coming from two sites not impacted by anthropogenic activities [25], Cacalomacan
TABLE 2: Criteria for evaluated moss enrichment factor.

\begin{tabular}{lc}
\hline Enrichment factor & Enrichment level \\
\hline$\leq 2$ & Conservative \\
$3-5$ & Slightly enriched \\
$6-9$ & Moderately enriched \\
$\geq 10$ & Highly enriched \\
\hline
\end{tabular}

and Ciervita (Figure 1), were considered as reference values. Consider

$$
\mathbf{E F}=\frac{\left(\mathbf{M}_{s} / \mathbf{T i}_{s}\right)_{\text {moss value }}}{\left(\mathbf{M}_{o} / \mathbf{T i}_{o}\right)_{\text {reference soils value }}}
$$

where $\mathbf{E F}$ is enrichment factor; $\mathbf{M}_{s}$ is concentration of metal " $x$ " in the moss sample; $\mathbf{T i}_{s}$ is concentration of conservative reference element (Ti) in the moss sample; $\mathbf{M}_{o}$ is concentration of metal " $x$ " in reference soils; and $\mathbf{T i}_{o}$ is concentration of conservative reference element (Ti) in reference soils.

In order to know the enrichment level by metals, several criteria were considered, as it appears in Table 2. Ratio values 
TABLE 3: Comparison between measured and reference elements concentration for the IAEA: Standard reference material: IAEA-336 Lichen.

\begin{tabular}{|c|c|c|c|c|c|c|}
\hline \multirow[b]{2}{*}{ Element } & \multicolumn{2}{|c|}{ Reference values } & \multicolumn{2}{|c|}{ Measured values } & \multirow{2}{*}{$\begin{array}{l}\mathrm{R} \\
\%\end{array}$} & \multirow{2}{*}{$\begin{array}{c}\mathrm{MDL} \\
\mathrm{mg} / \mathrm{Kg}\end{array}$} \\
\hline & $\begin{array}{c}\text { Mean } \\
\text { Concentration }\end{array}$ & $\mathrm{SD}$ & $\begin{array}{c}\text { Mean } \\
\text { Concentration }\end{array}$ & SD & & \\
\hline \multicolumn{7}{|c|}{$\mathrm{mg} / \mathrm{Kg}(n=9)$} \\
\hline $\mathrm{K}$ & 1840 & \pm 200 & 1745 & \pm 31 & 95 & 12 \\
\hline $\mathrm{Ca}$ & NR & NR & 2253 & \pm 172 & NC & 12 \\
\hline $\mathrm{Ti}$ & NR & NR & 14.77 & \pm 0.87 & NC & 3.5 \\
\hline $\mathrm{V}$ & 1.47 & \pm 0.22 & 1.37 & \pm 0.12 & 93 & 4.0 \\
\hline $\mathrm{Cr}$ & 1.06 & \pm 0.17 & 0.96 & \pm 0.10 & 91 & 1.8 \\
\hline $\mathrm{Mn}$ & 63 & \pm 7 & 62.54 & \pm 2.20 & 99 & 1.5 \\
\hline $\mathrm{Fe}$ & 430 & \pm 50 & 396 & \pm 22 & 92 & 1.2 \\
\hline $\mathrm{Ni}$ & NR & NR & $\mathrm{ND}$ & NC & $\mathrm{NC}$ & NC \\
\hline $\mathrm{Cu}$ & 3.6 & NR & 3.64 & \pm 0.21 & 101 & 1.3 \\
\hline $\mathrm{Zn}$ & 30.4 & \pm 3.4 & 34.88 & \pm 0.76 & 105 & 1.3 \\
\hline $\mathrm{Rb}$ & 1.76 & \pm 0.22 & 1.70 & \pm 0.06 & 97 & 0.23 \\
\hline $\mathrm{Sr}$ & 9.3 & \pm 1.1 & 9.35 & \pm 0.16 & 101 & 0.23 \\
\hline $\mathrm{Pb}$ & 4.9 & \pm 0.6 & 4.76 & \pm 0.04 & 97 & 0.50 \\
\hline
\end{tabular}

SD: standard deviation; R: recovery; NR: not reported; MDL: method detection limited; ND: not detected; NC: not calculated.

above 10.0 are generally considered to reflect enrichment of the element in mosses [26-28].

2.5. Statistical Methods. Data were processed by the Statgraphics Plus 5 program in order to obtain the average values, standard deviations, and confidence limits. The Statgraphics software allowed investigation of the existence of a normal distribution for the data values. The analysis of variance (ANOVA) was applied to data values when normal distribution was observed, and the Kruskal-Wallis test was used when no normal distribution law was observed, in order to deduce spatial distributions for heavy metals in the MZTV. The statistical methods were performed with a $95 \%$ confidence interval (CI; $\alpha=0.05)$.

\section{Results and Discussion}

The absence of a significant contamination during the digestion process of the samples was checked using blanks ( 2 for each digestion series of 14 samples) containing only supra pure grade quality acids. In order to evaluate the accuracy and reproducibility of the analytical results, three subsamples of the reference material "IAEA-336 Lichen" from the International Atomic Energy Agency (IAEA) were analyzed. The elemental concentrations in the samples are shown in Table 3. As it can be seen, the measured concentrations were consistent with the certified values. Accuracy being measured as the percentage of recoveries (\% R) after the acid digestion (ratio between values measured and certified in the reference material) was higher than $90 \%$ and the percentage relative error was from lower than $1 \%$ to $9 \%$. The relative standard deviation for all elements was lower than $10 \%$. Method detection limits (MDLs) for the experimental conditions are also shown.

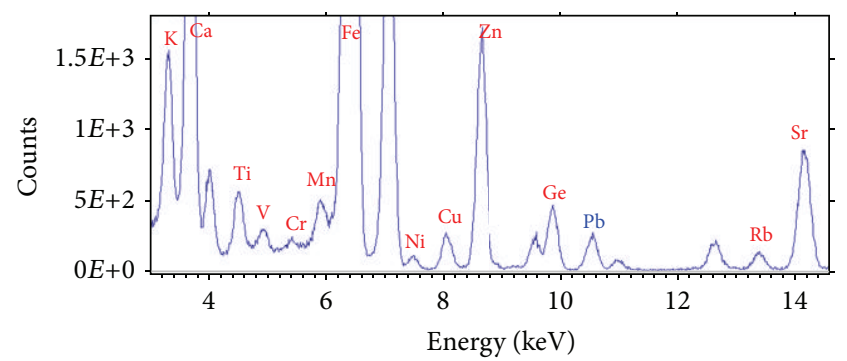

FIGURE 2: TXRF spectrum of a moss sample from Tollocan sampling site (6) at the Metropolitan Zone of the Valley of Toluca.

The K-lines of $\mathrm{K}, \mathrm{Ca}, \mathrm{Ti}, \mathrm{V}, \mathrm{Cr}, \mathrm{Mn}, \mathrm{Fe}, \mathrm{Ni}, \mathrm{Cu}, \mathrm{Zn}$, $\mathrm{Rb}, \mathrm{Sr}$, and L-lines of $\mathrm{Pb}$ were identified in moss samples. Figure 2 shows the TXRF spectrum of a moss sample in site 6 (Tollocan).

Mean and standard deviation of the analyzed metals in the mosses are given in Table 4 . The elements that showed the highest mean concentrations were $\mathrm{Fe}>\mathrm{Ca}>\mathrm{K}>\mathrm{Ti}>\mathrm{Zn}>$ $\mathrm{Mn}>\mathrm{Pb}>\mathrm{Sr}>\mathrm{Cu}>\mathrm{V}>\mathrm{Cr}>\mathrm{Rb}>\mathrm{Ni}$. In general the elements determinate present a variation in the concentration between different sampling sites (statistical significant differences, $P<$ 0.05).

$\mathrm{K}, \mathrm{Ca}, \mathrm{Ti}, \mathrm{Mn}, \mathrm{Fe}, \mathrm{Rb}$, and $\mathrm{Sr}$ are metals mainly associated with terrigenous sources, so their presence in airborne particulate matter in the study area may be due primarily to resuspension of soil, road dust, agricultural livestock, forest fires, and so forth [24, 28, 29]. On the other hand $\mathrm{V}, \mathrm{Cr}, \mathrm{Ni}, \mathrm{Cu}, \mathrm{Zn}$, and $\mathrm{Pb}$ in the MZTV can be associated mainly with anthropogenic sources, because even when these elements may be present naturally in soils they are considered like trace elements [30]; their presence in airborne particulate matter of the MZTV may be due 
TABle 4: Mean concentrations $\left(\mathrm{mg} \mathrm{kg}^{-1}\right)$ of elements in Fabronia ciliaris.

\begin{tabular}{|c|c|c|c|c|c|c|c|}
\hline \multirow[t]{2}{*}{ Element } & & $\begin{array}{c}\text { Site } 1 \\
\text { Alameda }\end{array}$ & $\begin{array}{c}\text { Site } 2 \\
\text { Reforma }\end{array}$ & $\begin{array}{c}\text { Site } 3 \\
\text { Hípico }\end{array}$ & $\begin{array}{c}\text { Site } 4 \\
\text { Pila }\end{array}$ & $\begin{array}{c}\text { Site } 5 \\
\text { Santin }\end{array}$ & $\begin{array}{c}\text { Site } 6 \\
\text { Tollocan }\end{array}$ \\
\hline & & \multicolumn{6}{|c|}{ Concentration in $\mathrm{mg} / \mathrm{Kg}(n=6)$} \\
\hline \multirow{2}{*}{ K } & Mean & 2824 & 4212 & 3787 & 4147 & 4771 & 4570 \\
\hline & SD & 138 & 115 & 308 & 234 & 240 & 254 \\
\hline \multirow{2}{*}{$\mathrm{Ca}$} & Mean & 4818 & 4589 & 5993 & 3880 & 10245 & 9275 \\
\hline & SD & 367 & 196 & 551 & 182 & 471 & 450 \\
\hline \multirow{2}{*}{$\mathrm{Ti}$} & Mean & 372 & 338 & 288 & 346 & 516 & 458 \\
\hline & SD & 29 & 10 & 17 & 16 & 18 & 22 \\
\hline \multirow{2}{*}{$\mathrm{V}$} & Mean & 29.20 & 34.22 & 19.23 & 27.23 & 23.02 & 90.92 \\
\hline & $\mathrm{SD}$ & 2.07 & 2.75 & 1.57 & 2.40 & 1.80 & 3.12 \\
\hline \multirow{2}{*}{$\mathrm{Cr}$} & Mean & 33.34 & 27.21 & 22.32 & 19.93 & 21.47 & 28.50 \\
\hline & SD & 2.10 & 0.80 & 1.15 & 1.12 & 1.46 & 1.20 \\
\hline \multirow{2}{*}{$\mathrm{Mn}$} & Mean & 172 & 119 & 132 & 161 & 292 & 214 \\
\hline & SD & 9 & 2 & 9 & 8 & 10 & 12 \\
\hline \multirow{2}{*}{$\mathrm{Fe}$} & Mean & 9332 & 6746 & 5616 & 6432 & 9562 & 10708 \\
\hline & SD & 696 & 191 & 310 & 214 & 232 & 344 \\
\hline \multirow{2}{*}{$\mathrm{Ni}$} & Mean & 10.88 & 11.08 & 7.40 & 6.20 & 8.65 & 19.04 \\
\hline & SD & 1.16 & 0.95 & 0.80 & 0.70 & 0.63 & 1.28 \\
\hline \multirow{2}{*}{$\mathrm{Cu}$} & Mean & 32.12 & 40.20 & 26.17 & 20.68 & 27.36 & 66.78 \\
\hline & SD & 2.26 & 0.86 & 1.00 & 0.81 & 1.38 & 2.58 \\
\hline \multirow{2}{*}{$\mathrm{Zn}$} & Mean & 145 & 179 & 151 & 136 & 220 & 406 \\
\hline & SD & 12 & 4.24 & 3 & 4 & 16 & 20 \\
\hline \multirow{2}{*}{$\mathrm{Rb}$} & Mean & 13.40 & 10.40 & 11.74 & 10.78 & 20.70 & 14.01 \\
\hline & SD & 0.50 & 0.70 & 0.73 & 0.64 & 1.00 & 1.00 \\
\hline \multirow{2}{*}{$\mathrm{Sr}$} & Mean & 40.54 & 41.01 & 67.00 & 45.80 & 49.14 & 109.00 \\
\hline & SD & 2.90 & 1.36 & 6.00 & 5.11 & 3.87 & 7.67 \\
\hline \multirow{2}{*}{$\mathrm{Pb}$} & Mean & 112 & 107 & 32.60 & 25.31 & 20.36 & 70.30 \\
\hline & SD & 5 & 2.38 & 2.26 & 1.60 & 1.51 & 3.81 \\
\hline Sum element concentration & & 17934 & 16543 & 16154 & 15254 & 25777 & 25999 \\
\hline
\end{tabular}

SD: standard deviation.

TABLE 5: Mean concentration in reference soils at the Metropolitan Zone of the Toluca Valley.

\begin{tabular}{lc}
\hline & Concentration in $\mathrm{mg} \mathrm{kg}^{-1}(n=36)$ \\
Element & Mean \\
\hline $\mathrm{K}$ & 6633 \\
$\mathrm{Ca}$ & 19563 \\
$\mathrm{Ti}$ & 3767 \\
$\mathrm{~V}$ & 95 \\
$\mathrm{Cr}$ & 51 \\
$\mathrm{Mn}$ & 852 \\
$\mathrm{Fe}$ & 30968 \\
$\mathrm{Ni}$ & 30 \\
$\mathrm{Cu}$ & 12 \\
$\mathrm{Zn}$ & 86 \\
$\mathrm{Rb}$ & $\mathrm{NR}$ \\
$\mathrm{Sr}$ & $\mathrm{NR}$ \\
$\mathrm{Pb}$ & 15 \\
\hline $\mathrm{NR}:$ not reported; Soil: values obtained from Tejeda et al., 2012 [34].
\end{tabular}

NR: not reported; Soil: values obtained from Tejeda et al., 2012 [34]. to mobile sources such as combustion products of oils, lubricants and additives for automotive, tire wear, brake, and stationary sources such as automotive, metalworking, smelter, and chromium industries established in the MZTV $[28,31]$.

In general, concentrations of $\mathrm{Cr}, \mathrm{Cu}, \mathrm{Zn}$, and $\mathrm{Pb}$ (Table 4) are the highest in sites Alameda, Reforma, and Tollocan (statistical significant differences, $P<0.05$ ), and additionally Tollocan presented a highest metal concentration sum compared to the other sampling sites (statistical significant differences, $P<0.05$ ), which can be related to traffic. It is known that the traffic is the main local source of contamination by metals like $\mathrm{V}, \mathrm{Cr}, \mathrm{Cu}, \mathrm{Zn}$, and $\mathrm{Pb}$, who can be associated with traffic emissions and other vehicular sources, such as combustion of fossil fuels, the wear of tires, brake linings, and asphalt $[6,28,32]$. Similar behavior in the concentration of these elements could be associated with all sites settled on primary roads with high traffic, an average of 53,000 vehicles/day [18].

Alameda and Reform showed a similar behavior; they are urban parks located in the center of the Toluca City, and 
TABLE 6: Moss enrichment factors (EFs) from samples sites at the Metropolitan Zone of the Toluca Valley.

\begin{tabular}{|c|c|c|c|c|c|c|c|}
\hline Element & $\begin{array}{c}\text { Site } 1 \\
\text { Alameda }\end{array}$ & $\begin{array}{c}\text { Site } 2 \\
\text { Reforma }\end{array}$ & $\begin{array}{c}\text { Site } 3 \\
\text { Hípico } \\
\end{array}$ & $\begin{array}{c}\text { Site } 4 \\
\text { Pila } \\
\end{array}$ & $\begin{array}{c}\text { Site } 5 \\
\text { Santin } \\
\end{array}$ & $\begin{array}{c}\text { Site } 6 \\
\text { Tollocan }\end{array}$ & EF mean \\
\hline $\mathrm{K}$ & 5 & 7 & 7 & 7 & 6 & 6 & 6 \\
\hline $\mathrm{Ca}$ & 2 & 2 & 3 & 2 & 4 & 4 & 3 \\
\hline $\mathrm{V}$ & 3 & 4 & 2 & 3 & 2 & 6 & 3 \\
\hline $\mathrm{Cr}$ & 7 & 5 & 5 & 4 & 3 & 5 & 5 \\
\hline $\mathrm{Mn}$ & 2 & 1 & 2 & 2 & 2 & 2 & 2 \\
\hline $\mathrm{Fe}$ & 3 & 2 & 2 & 2 & 2 & 3 & 2 \\
\hline $\mathrm{Ni}$ & 4 & 4 & 1 & 2 & 2 & 5 & 3 \\
\hline $\mathrm{Cu}$ & 26 & 33 & 24 & 18 & 16 & 45 & 27 \\
\hline $\mathrm{Zn}$ & 17 & 21 & 20 & 17 & 19 & 39 & 22 \\
\hline $\mathrm{Pb}$ & 76 & 72 & 24 & 18 & 10 & 39 & 40 \\
\hline
\end{tabular}

these sampling sites presented the highest lead concentration which can be associated with high buildings surrounding these parks who can contribute to this trend by obstructing pollution dispersion (so called resuspension phenomenon) of lead, copper, chromium, and zinc particles from metalmechanic and smelter industries located in the industrial zone of Toluca [18].

Tollocan and Santin presented the highest sum element concentration; both sampling sites are located near the industrial area of Lerma City and roads with high traffic of vehicles using gasoline and diesel, an average 85000 vehicles/day [18]. $\mathrm{Ti}, \mathrm{Fe}$, and $\mathrm{Mn}$ may also have terrigenous source, as they are more exposed to the deposition of particles from soil resuspension and transport of fugitive dust because there are no prominent topographic barriers.

The enrichment factors determined in this study in relation to the composition of reference soils (Table 5) showed that elements $\mathrm{Ca}, \mathrm{V}, \mathrm{Mn}, \mathrm{Fe}$, and $\mathrm{Ni}$ are conservatives (terrigenous origin) typical constituents of soils included in content of aerosols [33], may originate from resuspension of soil and road dust, but also may be derived partly from some anthropogenic sources.

According to the criteria proposed $\mathrm{K}$ and $\mathrm{Cr}$ show a slightly-moderately enriched (Table 6) indicated that the sources were mainly pedological-soil or substrate contribution and anthropogenic activities, while high $\mathrm{EF}$ for $\mathrm{Cu}, \mathrm{Zn}$, and $\mathrm{Pb}$ pointed to a predominantly anthropogenic origin $(\mathrm{EF}>10)$.

Alameda and Reform presented the highest lead EF; both are urban parks located in the center of the city of Toluca with high vehicular traffic, while in Tollocan site, the mosses presented high $\mathrm{Cu}, \mathrm{Zn}$, and $\mathrm{Pb}$ enrichment, these elements are considered as indicators of emission from fossil fuel combustion processes, including vehicle exhausts; so these sites may pose a risk to people living or working in these areas, because the exposure to long- and short-term particulate matter $\left(\leq \mathrm{PM}_{10}\right)$ can cause decreased lung function, which contributes to the presence of chronic respiratory diseases and premature death; on the other hand, according to the results of recent studies by the Institute of Health of the State of Mexico in the MZTV, the climate, altitude, wind circulation, and Urban and industrial growth, among others, make this area emphasize the likelihood of having high concentrations of small suspended particles.

\section{Conclusions}

The accuracy related to the sample preparation and the measurement with the TXRF equipment was acceptable (R: 91\%-105\%), which was demonstrated by the use of the standard reference material. In relation to the reproducibility the results show a good standard deviation $(\mathrm{SD}<10 \%)$.

TXRF was used to measure a wide range of elements in the epiphytic moss, which has the ability to accumulate metals and therefore can be used as a bioindicator of anthropogenic activities in polluted metropolitan zones, since this organism is sensible to the variations of elemental concentrations in the atmosphere.

The analysis of moss does provide information about the presence of contaminants in the atmosphere, their spatial patterns of distribution, and how they are taken up by live organisms.

Most of the data concentrations in the Fabronia ciliaris of the sampling sites Alameda (1), Reforma (2), and Tollocan (3) were higher than concentrations in the other sampling sites due to the level of pollution in the atmosphere.

\section{Acknowledgment}

Authors acknowledge the support provided by the National Council of Science and Technology (CONACyT), research project Code EDOMEX-2010-CO-046.

\section{References}

[1] L. Barandovski, M. Cekova, M. V. Frontasyeva et al., "Atmospheric deposition of trace element pollutants in Macedonia studied by the moss biomonitoring technique," Environmental Monitoring and Assessment, vol. 138, no. 1-3, pp. 107-118, 2008.

[2] A. Mulgrew and P. Williams, Biomonitoring of Air Quality Using Plants, WHO Collaborating Centre for Monitoring and Assessment, Berlin, Germany, 2000. 
[3] M. T. Boquete, J. A. Fernández, J. R. Aboal, and A. Carballeira, "Analysis of temporal variability in the concentrations of some elements in the terrestrial moss Pseudoscleropodium purum," Environmental and Experimental Botany, vol. 72, no. 2, pp. 210216, 2011.

[4] H. G. Zechmeister, K. Grodziñska, and G. Szarek-Cukaszewska, "Bryophytes," in Bioindicators and Biomonitors, B. A. Markert, A. M. Breure, and H. G. Zechmeister, Eds., Elsevier, Amsterdam, The Netherlands, 2003.

[5] G. Tyler, "Bryophytes and heavy metals: a literature review," Botanical Journal of the Linnean Society, vol. 104, pp. 231-253, 1990.

[6] A. H. Tremper, M. Agneta, S. Burton, and D. E. B. Higgs, "Field and laboratory exposures of two moss species to low level metal pollution," Journal of Atmospheric Chemistry, vol. 49, no. 1-3, pp. 111-120, 2004.

[7] T. Berg, O. Royset, and E. Steinnes, "Moss (Hylocomium splendens) used as biomonitor of atmospheric trace element deposition: estimation of uptake efficiencies," Atmospheric Environment, vol. 29, no. 3, pp. 353-360, 1995.

[8] T. Berg and E. Steinnes, "Use of mosses (Hylocomium splendens and Pleurozium schreberi) as biomonitors of heavy metal deposition: from relative to absolute deposition values," Environmental Pollution, vol. 98, no. 1, pp. 61-71, 1997.

[9] A. Rühling, "Atmospheric heavy metal deposition in Europe," in Estimations Based on Moss Analysis, p. 9, Nordic Council of Ministers, Copenhagen, Denmark, 1994.

[10] R. Gerdol, L. Bragazza, R. Marchesini et al., "Monitoring of heavy metal deposition in Northern Italy by moss analysis," Environmental Pollution, vol. 108, no. 2, pp. 201-208, 2000.

[11] K. Grodzinska, G. Szarek, and B. Godzik, "Heavy metal deposition in polish national parks-changes during ten years," Water, Air, and Soil Pollution, vol. 49, no. 3-4, pp. 409-419, 1990.

[12] H. Harmens, D. A. Norris, G. R. Koerber, A. Buse, E. Steinnes, and Å. Rühling, "Temporal trends (1990-2000) in the concentration of cadmium, lead and mercury in mosses across Europe," Environmental Pollution, vol. 151, no. 2, pp. 368-376, 2008.

[13] B. Markert, U. Herpin, C. J Berlekamp et al., "A comparison of heavy metal deposition in selected Eastern European countries using the moss monitoring method, with special emphasis on the 'Black Triangle," Science of the Total Environment, vol. 193, no. 2, pp. 85-100, 1996.

[14] B. Markert, U. Reus, and U. Herpin, "The application of TXRF in instrumental multielement analysis of plants, demonstrated with species of moss," Science of the Total Environment, vol. 152, no. 3, pp. 213-220, 1994.

[15] J. A. Fernández, A. Rey, and A. Carballeira, "An extended study of heavy metal deposition in Galicia (NW Spain) based on moss analysis," Science of the Total Environment, vol. 254, no. 1, pp. 3144, 2000.

[16] J. R. Aboal, J. A. Fernández, T. Boquete, and A. Carballeira, "Is it possible to estimate atmospheric deposition of heavy metals by analysis of terrestrial mosses?" Science of the Total Environment, vol. 408, no. 24, pp. 6291-6297, 2010.

[17] A. Miller, Climatología, Omega, Barcelona, Spain, 1982.

[18] Secretaria del Medio Ambiente, Aire limpio: Programa para el Valle de Toluca 2007-2011, Gobierno del Estado de México, México City, Mexico, 2007.

[19] A. Carballeira and J. López, "Physiological and statistical methods to identify background levels of metals in aquatic bryophytes: dependence on lithology," Journal of Environmental Quality, vol. 26, no. 4, pp. 980-988, 1997.

[20] CEM, Methods for Microwave Accelerated Reaction System for Acid Digestion, CEM Corporation, Matthews, NC, USA, 2001.

[21] Deutsches Institut für Normung EV, “Total reflection x-ray fluorescence analysis (TXRF)," German Norm: E DIN, 51003:200101, 2001.

[22] Ital-Structures, TX2000 Spectrometer: guide to the user, Italy, 2000.

[23] R. Klockenkämper, Total-Reflection X-Ray Fluorescence Analysis, John Wiley \& Sons, New York, NY, USA, 1997.

[24] W. Salomons and U. Förstner, Metals in the Hidrocycle, Springer, New York, NY, USA, 1984.

[25] R. Bargagli, D. H. Brown, and L. Nelli, "Metal biomonitoring with mosses: procedures for correcting for soil contamination," Environmental Pollution, vol. 89, no. 2, pp. 169-175, 1995.

[26] R. J. Lantzy and F. T. Mackenzie, "Atmospheric trace metals: global cycles and assessment of man's impact," Geochem Cosmochem Acta , vol. 43, no. 4, pp. 511-525, 1979.

[27] S. Dragović and N. Mihailović, "Analysis of mosses and topsoils for detecting sources of heavy metal pollution: multivariate and enrichment factor analysis," Environmental Monitoring and Assessment, vol. 157, no. 1-4, pp. 383-390, 2009.

[28] M. Aničić, M. Frontasyeva, M. Tomašević, and A. Popović, "Assessment of atmospheric deposition of heavy metals and other elements in Belgrade using the moss biomonitoring technique and neutron activation analysis," Environmental Monitoring and Assessment, vol. 129, pp. 207-219, 2007.

[29] P. M. Chapman, F. Wang, C. R. Janssen, R. R. Goulet, and C. N. Kamunde, "Conducting ecological risk assessments of inorganic metals and metalloids: current status," Human and Ecological Risk Assessment, vol. 9, no. 4, pp. 641-697, 2003.

[30] A. Ure and M. Berrow, The Chemical Constituents of Soils, H. J. M. Bowen, Ed., Royal Society of Chemistry in Burlington House, London, UK, 1982.

[31] F. Monaci, F. Moni, E. Lanciotti, D. Grechi, and R. Bargagli, "Biomonitoring of airborne metals in urban environments: new tracers of vehicle emission, in place of lead," Environmental Pollution, vol. 107, no. 3, pp. 321-327, 2000.

[32] S. R. Oliva and P. Rautio, "Could ornamental plants serve as passive biomonitors in urban areas?" Journal of Atmospheric Chemistry, vol. 49, no. 1-3, pp. 137-148, 2004.

[33] W. C. Malm, J. F. Sisler, D. Huffman, R. A. Eldred, and T. A. Cahill, "Spatial and seasonal trends in particle concentration and optical extinction in the United States," Journal of Geophysical Research, vol. 99, no. 1, pp. 1347-1370, 1994.

[34] S. Tejeda, G. Zarazúa, and F. Astivia, "Geochemical analysis of soils from metropolitan zone of the Toluca Valley," Tech. Rep., National Institute for Nuclear Research, México City, Mexico, 2012. 

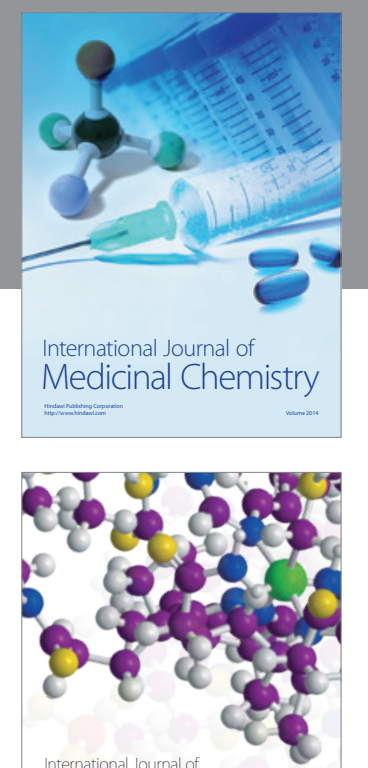

\section{Carbohydrate} Chemistry

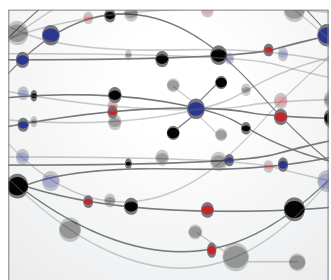

The Scientific World Journal
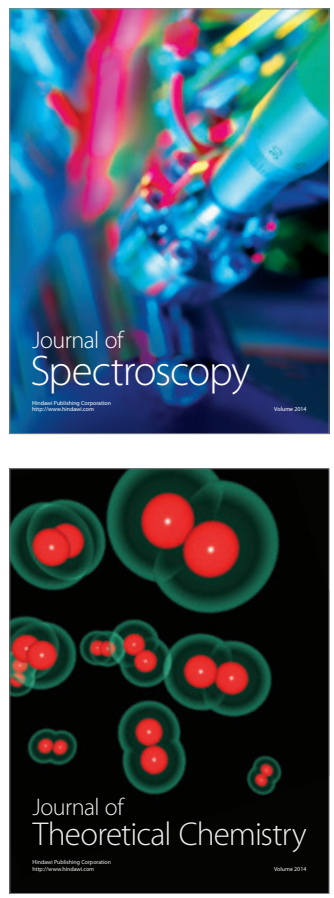
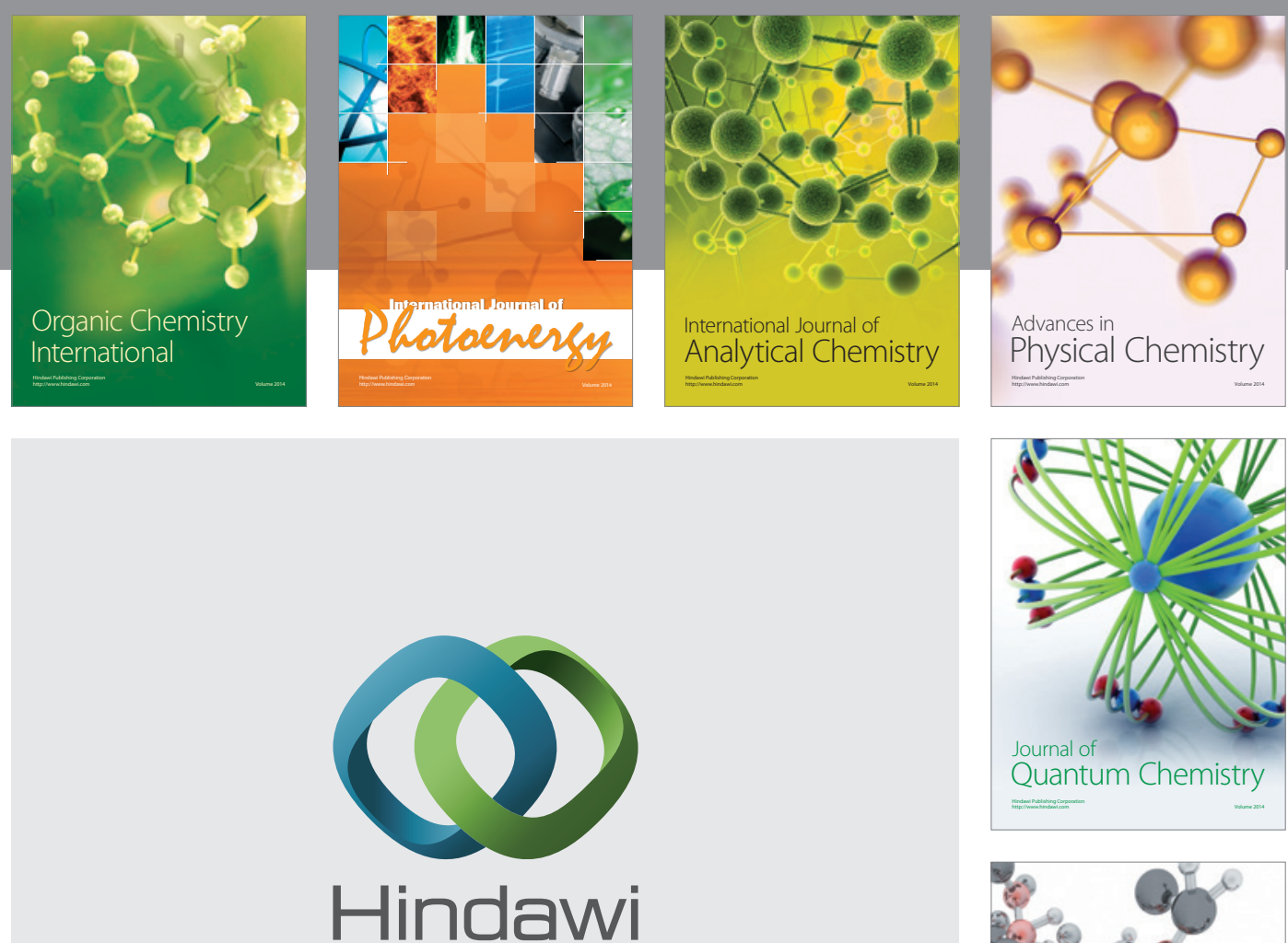

Submit your manuscripts at

http://www.hindawi.com

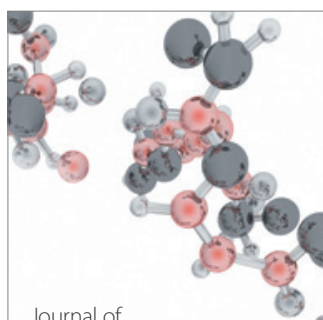

Analytical Methods

in Chemistry

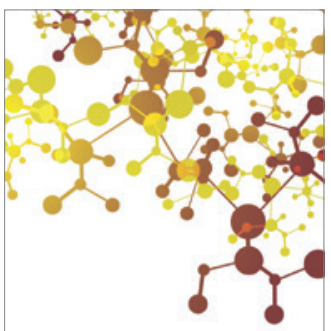

Journal of

Applied Chemistry

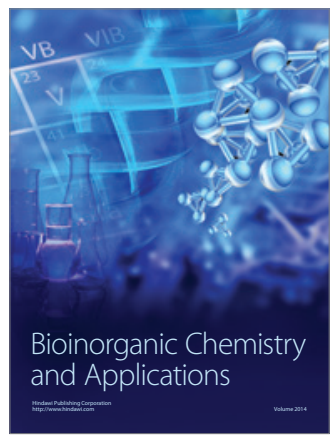

Inorganic Chemistry
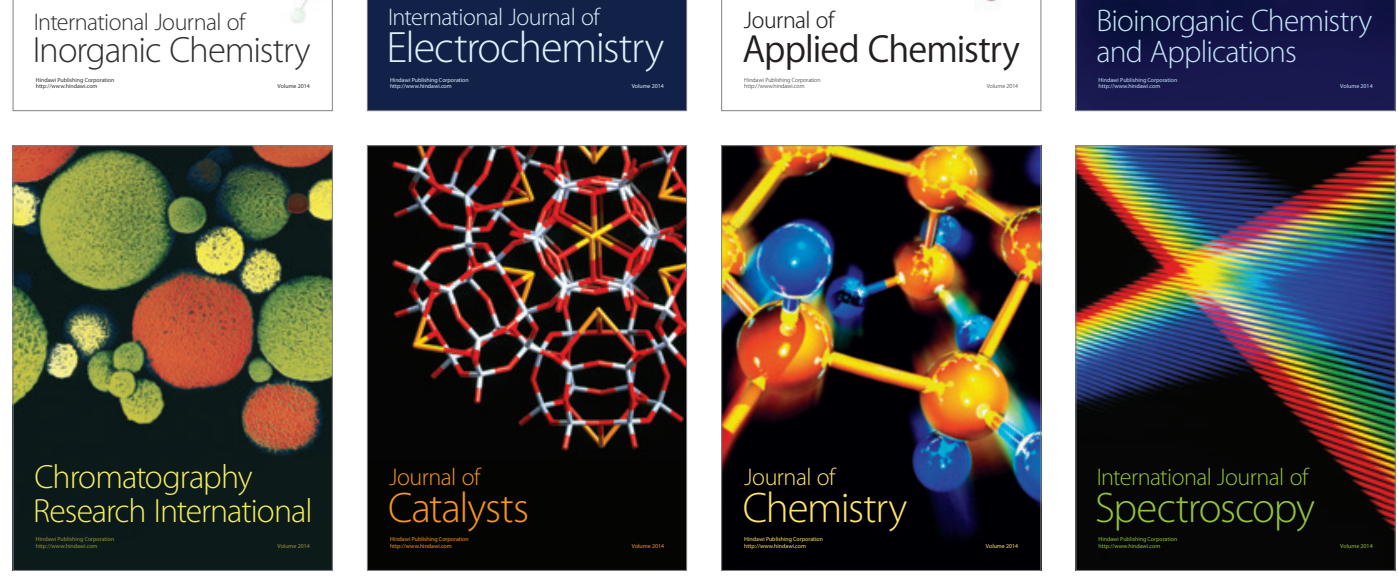